\title{
マッハ数を考慮したサイドジェットの形成条件
}

\section{Effects of Mach number, momentum thickness ratio and density ratio on the side-jet formation in round jets with variable-density}

\author{
O正 村松 且典（日大·理工）学 金田 康宏（日大院・理工） \\ 岩倉 徹（日大·理工）高橋 真璃子（日大・理工）
}

\begin{abstract}
Akinori MURAMATSU, Nihon University, College of Science and Technology, Narashino-dai, Funabashi 274-8501 Yasuhiro KANEDA, Nihon University, Graduate School of Science and Technology, Narashino-dai, Funabashi 274-8501

Toru IWAKURA, Nihon University, College of Science and Technology, Narashino-dai, Funabashi 274-8501 Mariko TAKAHASHI, Nihon University, College of Science and Technology, Narashino-dai, Funabashi 274-8501
\end{abstract}

\begin{abstract}
When a low density gas compared with the ambient gas is discharged from a round nozzle, side jets that are radial ejections of jet fluid are generated at the initial region. The density ratio between the jet fluid and the ambient fluid is a main parameter for side-jet formation. Since the side-jet formation is also related to the instability of shear layer, another parameter is a ratio of the momentum thickness and the nozzle diameter at the nozzle exit. Compressibility suppresses the generation of the side jets. The variable-density jets were issued from two round nozzles, which have different area contraction ratio, with various jet-speed. Effects of the density ratio, the momentum thickness ratio and the Mach number, which is defined by the issuing conditions, on the side-jet formation are researched experimentally. An existence of side jets was confirmed by flow visualization using a laser sheet.
\end{abstract}

Key Words: Side jet, Variable density jet, Round jet, Instability, Mach number, Momentum thickness, Density ratio

\section{1.はじめに}

周囲流体より噴出流体の密度が十分に低い円形噴流の初 期領域で, サイドジェット(1) 〜 (3) と呼ばれる噴流コア領域 から半径方向外側への流出現象を生じる場合がある. サイド ジェットが形成されると, 噴流初期領域から周囲流体と噴流 流体との混合が起こり，噴流による流体混合が促進される. しかし，サイドジェットがどのようなメカニズムで形成され るのか, サイドジェットがどのような条件のもとで形成され るか，といった具体的なことは未だにわかっていない.

サイドジェットの形成条件に関して, Monkewitz ら ${ }^{(4)}$ は 加熱した円形空気噴流を対象として線型安定解析を行い, 噴 流流体と周囲流体との密度比 $S$ が 0.72 以下で, 噴流の噴出速 度を周囲流体の音速で無次元化したマッ八数 $M$ があまり大 きくないとき, 噴流が局所的に絶対不安定となることを示し た.さらに, Monkewitz ら (1) はこの局所絶対不安定となる 条件下で実験を行い, 噴流が自励振動しサイドジェットが生 じることを示した. また, サイドジェットの形成には噴流剪 断層の Kelvin-Helmholtz 不安定が関係するので, 噴流の剪断 層が薄く速度勾配が大きいときにサイドジェットが生じや すい.これを定量的に評価するためのパラメータとして，ノ ズル出口での運動量厚さ $\theta_{0}$ とのノズル出口直径 $D_{0}$ の比 $D_{0} / \theta_{0}$ が使用されている ${ }^{(2)}$, (5). Kaneda ら ${ }^{(5)}$ はサイドジェット形 成のための $D_{0} / \theta_{0}$ の下限の值はおおよそ 20 であることを示し ている.

Monkewitz ら (4) が示したように, 圧縮性によりサイド ジェットの形成が阻害されると考えられるので，ここでは Kaneda らの実験 ${ }^{(5)}$ においてパラメータとした密度比 $S$ と運 動量厚さの比 $D_{0} / \theta_{0}$ に, マッハ数 $M$ を加えてサイドジェット の形成条件を実験的に調べた。

\section{2. 実験装置および方法}

実験に使用した噴出気体はへリウムガス, ヘリウムガスと 空気の混合気体, 空気および炭酸ガスである.これらの気体 を出口直径 $D_{0}=8 \mathrm{~mm}$ の円形ノズルから鉿直上方に静止大気 中へ噴出した. 円形ノズルの面積縮流比 $C R$ は 9.8 と 68.1 で あり, 主に前者のノズルを使用した. 噴出気体の密度 $\rho_{0}$ と
周囲気体（ここでは空気）の密度 $\rho_{\infty}$ で定義される密度比 $S=\rho_{0} / \rho_{\infty}$ は $0.14,0.3,0.5,0.6,0.65,0.7,0.75,0.8,1$ および 1.53 に設定した. なお，同一の噴出速度，すなわち同 一の噴流レイノルズ数 Reにおいて，ノズル出ロで形成され る剪断層の速度勾配, すなわち運動量厚さを変えるために, 面積縮流比 $C R$ を変えている. ここで, 噴流レイノルズ数 $R e$ は $R e=U_{\mathrm{c} 0} \cdot D_{0} / \nu_{0}$ で定義され， $U_{\mathrm{c} 0}$ はノズル出口での中心 軸上速度， $v_{0}$ は噴出気体の動粘性係数である.

ノズル出ロより $0.5 \mathrm{~mm}$ 下流での噴流の半径方向速度分布 を熱線濃度計と熱線風速計を併用して測定した. 測定された 速度分布の形状を双曲正接関数で近似してから積分を行い, 運動量厚さ $\theta_{0}$ を求めた ${ }^{(5)}$. ここで， $\theta_{0}$ はノズル出口におけ る噴流に形成される剪断層の厚み, 寸なわち速度勾配を定量 化するために用いているので, 剪断層に形成される濃度境界 層内の密度変化は考慮しない值を用いる ${ }^{(6)}$. サイドジェット

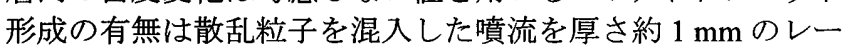
ザシートにより可視化して調べた.

\section{3. 実験結果および考察}

噴出気体がノズルより層流境界層を形成して噴出される とき, 図 1 に示されるように運動量厚さ $\theta_{0}$ は $1 / \sqrt{R e}$ に比例し, 密度比 $S$ にほとんど依存しない ${ }^{(5)} . \theta_{0} / D_{0}$ は面積縮流比 $C R$ によって変わり, 次式で近似できる.

$$
\begin{aligned}
\theta_{0} / D_{0} & =1.09 / \sqrt{\operatorname{Re}} \quad(C R=9.8) \\
& =0.837 / \sqrt{\operatorname{Re}} \quad(C R=68.1)
\end{aligned}
$$

図 2 に噴流を可視化した写真を示す. サイドジェットは噴 流が乱流へ遷移する前のコア領域からの噴流半径方向外側 への流出現象として判断している ${ }^{(7)}$. すなわち, 図 2(a)がサ イドジェットを形成する場合, 図 2(c)が形成しない場合とな る. 図 2(b)ような微小な周囲方向への噴出がある噴流は空気 噴流でも観察されることがあり形成の有無を判断できない とする. 図 2(a), (b), (c)の噴流に対して, それぞれ記号を○,

A, 使って識別結果を表わすことにする.

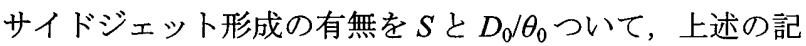




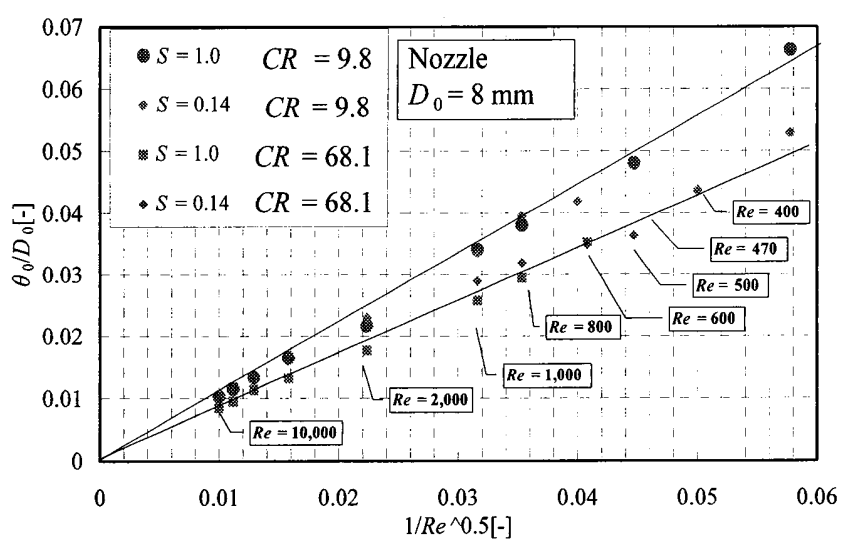

Fig. 1 A relationship between momentum thickness ratio and jet Reynolds number

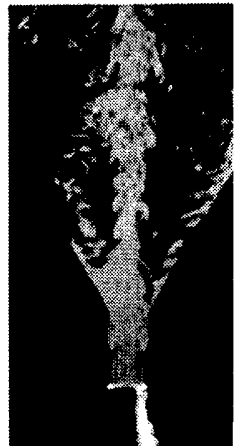

(a) Side jet

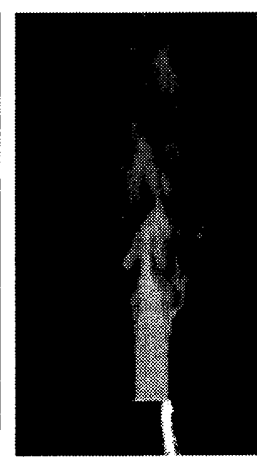

(b) Undecided 4

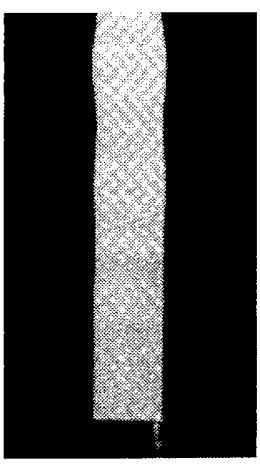

(c)No side jet
Fig. 2 Examples for determination of side-jet formation

(a) $S=0.17, D_{0} / \theta_{0}=26, M=0.03$

(b) $S=0.80, D_{0} / \theta_{0}=58, M=0.03$

(c) $S=0.14, D_{0} / \theta_{0}=22.5, M=0.02$

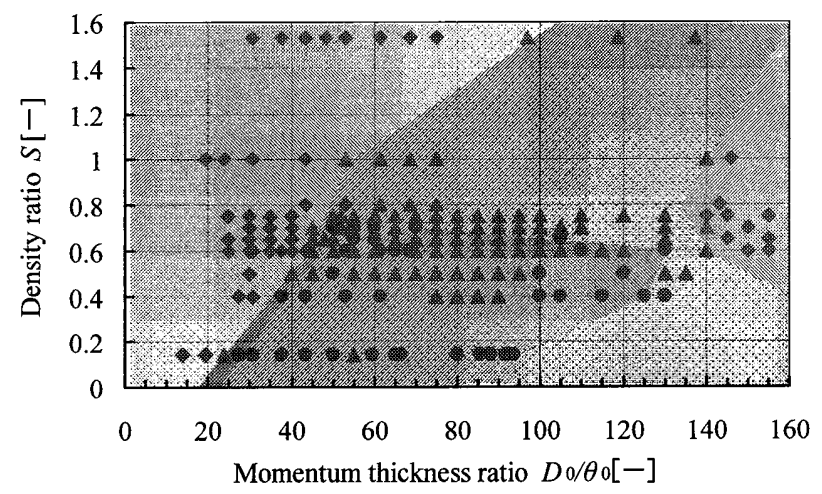

Fig. 3 A domain for side-jet formation by density ratio and momentum thickness ratio

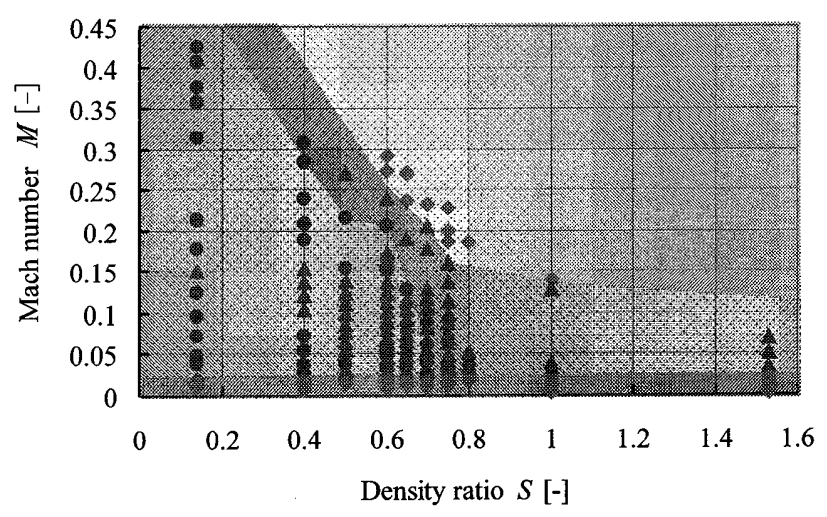

Fig. 4 A domain for side-jet formation by density ratio and Mach number

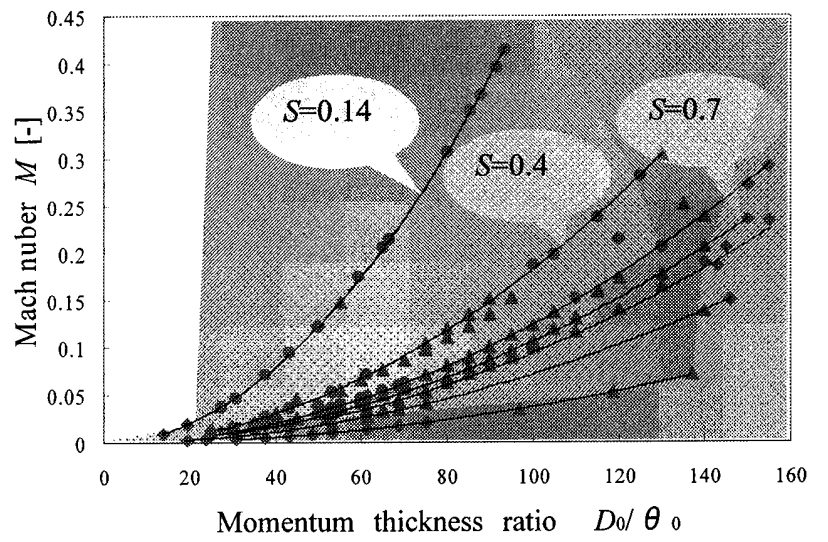

Fig. 5 A domain for side-jet formation by Mach number and momentum thickness ratio

号○，《，使って整理すると図 3 のようになる.サイド ジェットが形成される領域 (赤), 判別が出来ない領域（青） とサイドジェットが生じない領域（緑）として色分けした. $D_{0} / \theta_{0}$ が大きくなると，すなわち，速度勾配，または Reが大 きくなってもサイドジェットが形成されない領域があるこ とがわかる.サイドジェットが形成される領域 (赤) の $D_{0} / \theta_{0}$ の上限值は約 130 であり, Kyle らの自励振動が生じる上限值 $120^{(2)}$ とほぼ一致している。 また， $S$ の上限值は約 0.7 であ り, Monkewitz らの実験值 (1) と一致する.

次に, $S$ と $M$ について, 図 3 と同様に整理した結果を図 4 に示す. 赤色で示されるサイドジェット形成領域に上限と 下限の值が存在する. $M$ の下限值は $S$ の值によらず約 0.03 の值をとる. 一方, $M$ の上限の值は $S$ が小さいほど大きく, $S$ の上限值である 0.7 では $M$ は約 0.06 となった. Monkewitz らの安定解析では $S=0.5$ で $M=0.3$ が上限值である ${ }^{(4)}$ が, 本実験では $M=0.21$ となり, おおよそ一致している. なお, $M$ の増加によって, 一般的に乱れの増幅が抑えられる傾向に あることが知られている。

密度比 $S$ をパラメータにして, 運動量厚さの比 $D_{0} / \theta_{0}$ を横 軸に, マッ八数 $M$ を縦軸にしてサイドジェット形成領域の 関係を表した図を, 図 5 示す. $D_{0} / \theta_{0}$ が小さくなると, Kelvin-Helmholtz 不安定による剪断層のロールアップが起こ らずサイドジェットが形成されないと考えられるので, $D_{0} / \theta_{0}$ には $M$ に応じて下限が存在するはずであるが, 現時点では 不明であり，図 5 において色をつけていない。

\section{引用文献}

(1) P. A. Monkewitz, D.W. Bechert, B. Barsikow and B. Lehmann., Self-excited oscillation and mixing in a heated round jet, J. Fluid Mech., 213 (1990) , pp. 619-639.

(2) D. M. Kyle and K. R. Sreenivasan, The instability and breakdown of a round variable-density jet, J. Fluid Mech., 249 (1993), pp.619-664.

(3) A. Muramatsu, M. Gamba, and T. N. Clemens, Side jets generated in a round helium gas jet, 2nd International Conference on Jets, Wakes, and Separated Flows, CD-R (2008).

(4) P. A. Monkewitz and K. D. Sohn, Absolute instability in hot jets, AIAA J., 26 (1988), pp.911-916.

(5) Y. Kaneda and A. Muramatsu, Effects on momentum thickness and density ratio for side-jet formation in round jets with variable-density, Proceedings of ASME-JSME-KSME Joint Fluids Engineering Conference 2011, USB (2011).

(6) Michalke, A., Survey on jet instability theory, Prog. Aerospace Sci., 21, (1984), pp.159-199.

(7) Muramatsu, A., Side-jet formation in pulsed air jets. 3rd International Conference on Jets, Wakes, and Separated Flows, CD-R (2010). 